\title{
Preparation of Calcium Phosphate with Oyster Shells
}

\author{
Hiroaki Onoda, Hironari Nakanishi \\ Department of Informatics and Environmental Sciences, Kyoto Prefectural University, Kyoto, Japan. \\ Email: onoda@kpu.ac.jp
}

Received April 16 ${ }^{\text {th }}$ 2012; revised May 10 ${ }^{\text {th }}, 2012$; accepted May $18^{\text {th }}, 2012$

\begin{abstract}
Oyster shells have received attention for use as a calcium resource. For this study, calcium phosphate was prepared from phosphoric acid and oyster shells. The influences of the concentration of phosphoric acid and $\mathrm{pH}$ in the preparation conditions were studied from the yields of calcium phosphate and unreacted carbonate, and the $\mathrm{Ca} / \mathrm{P}$ ratios in precipitates. The yield of calcium phosphate and carbonate was low in the preparation condition with $0.1 \mathrm{~mol} / \mathrm{l}$ of phosphoric acid. The obtained precipitates were the mixture of calcium hydrogen phosphate dihydrate and the unreacted calcium carbonate. The reactivity of the oyster shells with phosphoric acid was discussed from the yields and Ca/P ratios in precipitates.
\end{abstract}

Keywords: Calcium Phosphate; Oyster Shells; Calcium Carbonate; Yield; Powder Properties

\section{Introduction}

Recently, interest in the recycling of waste materials is increasing. From this viewpoint, seashells have been used as a raw material for various applications [1,2]. Generally, edible parts of shellfish are few. Therefore, large amounts of waste material are produced from shellfish processing. Because seashells are easy to gather, they are suitable for use as a raw material. To date, seashells that are light with little pigment, for example scallops, have been used as a calcium resource [3,4]. Nevertheless, it is difficult to use seashells that are dark and which have much pigment.

Calcium phosphates are important materials for many applications, such as ion exchangers, adsorbents, and so on $[5,6]$. Calcium phosphates were prepared from sea urchin shells and artificial phosphorus waste fluid in earlier studies [7,8]. The obtained precipitates' main component was $\mathrm{CaHPO}_{4} \cdot 2 \mathrm{H}_{2} \mathrm{O}$. The precipitates containing organic coloring materials were obtained in the process with the sea-urchin shell heated at lower temperatures as a pretreatment. Sea urchin shells have overly strong coloring materials. In contrast, corbicula and oyster shells were expected to produce calcium phosphate with fewer coloring materials [9]. In previous work, corbicula shells were used to prepare calcium phosphate [10]. The corbicula shells with and without heating reacted with phosphoric acid to calcium hydrogen phosphate dihydrate. Oyster is one of the popular seafoods in all over the world. Therefore, the oyster shells are easy to gather, these oyster shells have a possibility to use as one of calcium resource.
In this work, we tried to use this oyster shell as a calcium resource to prepare calcium phosphate. The concentration of phosphoric acid and $\mathrm{pH}$ value were varied to clarify the formation mechanism of calcium phosphate. The chemical composition and powder properties of precipitates were investigated. The obtained phosphate materials were also assessed for the comparison with calcium phosphate prepared from phosphoric acid and commercial calcium carbonate.

\section{Experimental}

Oyster shells were washed and milled to a powder condition. Half were heated at $400^{\circ} \mathrm{C}$ for 1 hour. The shell powders without heating and heated at $400^{\circ} \mathrm{C}$ were mixed with $0.1,0.05$, and $0.01 \mathrm{~mol} / \mathrm{l}$ of phosphoric acid in the ratio of $\mathrm{Ca} / \mathrm{P}=1,2$, and 10 , respectively. At this time, the weight of oyster shells was calculated as that of calcium carbonate. These solutions were adjusted with am-

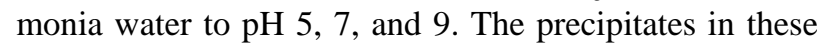
solutions were filtered off and dried. For comparison, commercial calcium carbonate was reacted with phosphoric acid in the same conditions as those used for oyster shells.

A part of the precipitates was dissolved in hydrochloric acid solution. The ratios of phosphorus and calcium in the precipitates were also calculated from ICP results of these solutions, using SPS1500VR, Seiko Instruments Inc. XRD patterns of materials were recorded on a Rigaku Denki RINT 2000 X-Ray diffractometer using monochromated $\mathrm{CuK} \alpha$ radiation. 
Furthermore, the powder properties of the obtained precipitates were estimated from the particle shape and size distribution. Scanning electron microscopy (SEM) images of samples were observed using JGM-5510LV, JEOL Ltd. The particle size distributions of these materials were measured with laser diffraction/scattering particle size distribution HORIBA LA-910.

\section{Results and Discussion}

\subsection{Preparation of Calcium Phosphates}

The phosphorus-rich solution disturbs the water environment at many points in the world [11]. Therefore, in this work, the concentration of phosphoric acid changed to a lower one to prevent the phosphorus-rich filtered solution. At low phosphoric acid concentration, not all of the oyster shells were able to react with phosphoric acid. Table $\mathbf{1}$ presents the yields of precipitates obtained in various conditions. This yield was calculated on the assumption that the obtained precipitate was a mixture of $\mathrm{CaHPO}_{4} \cdot 2 \mathrm{H}_{2} \mathrm{O}$ and $\mathrm{CaCO}_{3}$. The yield of calcium phosphate and carbonate was low in the preparation condition with $0.1 \mathrm{~mol} / \mathrm{l}$ of phosphoric acid. On the other hand, the yields in the conditions with 0.05 and $0.01 \mathrm{~mol} / \mathrm{l}$ of phosphoric acid were higher than those with $0.1 \mathrm{~mol} / \mathrm{l}$ of phosphoric acid, because of the unreacted calcium carbonate and insoluble part of oyster shells. The yields became lower by the reaction with phosphoric acid. Oyster shells without heating indicated high yields by using $0.01 \mathrm{~mol} / \mathrm{l}$ of phosphoric acid, because this condition was unsuitable to react with phosphoric acid. In the whole, oyster shells indicated the lower yields of calcium phosphate than corbicula shells reported in previous work [10]. The conditions of corbicula shells with heating and $0.1 \mathrm{~mol} / \mathrm{l}$ of phosphoric acid indicated over $90 \%$ in the yields. Oyster shells had the different behavior in the reactivity with phosphoric acid from corbicula shells.

The ratio of $\mathrm{CaHPO}_{4} \cdot 2 \mathrm{H}_{2} \mathrm{O}$ and $\mathrm{CaCO}_{3}$ in precipitates was estimated from $\mathrm{Ca} / \mathrm{P}$ ratio in the results of ICP measurements. Table 2 shows $\mathrm{Ca} / \mathrm{P}$ ratio in precipitates from ICP results. The theoretical $\mathrm{Ca} / \mathrm{P}$ ratio was 1,2 , and 10 in the cases with $0.1,0.05$, and $0.01 \mathrm{~mol} / \mathrm{l}$ of phosphoric acid, respectively. The $\mathrm{Ca} / \mathrm{P}$ ratio in $\mathrm{CaHPO}_{4}$ is 1 , therefore the difference from this ratio was related with that the precipitates contained calcium carbonate. Samples prepared with 0.05 and $0.01 \mathrm{~mol} / \mathrm{l}$ of phosphoric acid had smaller ratio of $\mathrm{Ca} / \mathrm{P}$ than theoretical ratio.

Table 1. Yeilds of samples prepared with oyster shells $/ \mathrm{s} \%$.

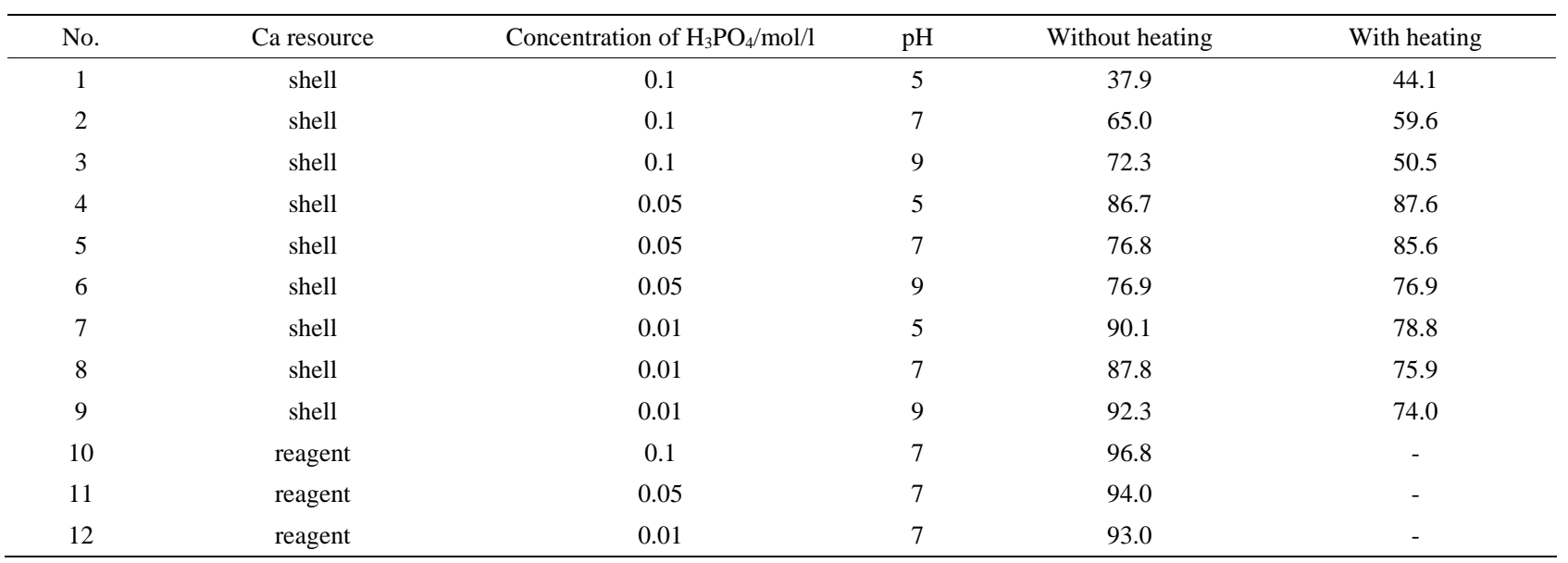

Table 2. Ca/P ratios in precipitates from ICP measurements.

\begin{tabular}{|c|c|c|c|c|c|}
\hline No. & Ca resource & Concentration of $\mathrm{H}_{3} \mathrm{PO}_{4} / \mathrm{mol} / \mathrm{l}$ & $\mathrm{pH}$ & Without heating & With heating \\
\hline 1 & shell & 0.1 & 5 & 1.19 & 1.30 \\
\hline 2 & shell & 0.1 & 7 & 0.78 & 1.37 \\
\hline 3 & shell & 0.1 & 9 & 0.82 & 1.50 \\
\hline 4 & shell & 0.05 & 5 & 1.55 & 0.70 \\
\hline 5 & shell & 0.05 & 7 & 0.85 & 0.89 \\
\hline 6 & shell & 0.05 & 9 & 0.97 & 1.04 \\
\hline 8 & shell & 0.01 & 7 & 2.73 & 3.73 \\
\hline 9 & shell & 0.01 & 9 & 4.91 & 4.84 \\
\hline 10 & reagent & 0.1 & 7 & 1.13 & - \\
\hline 11 & reagent & 0.05 & 7 & 2.32 & - \\
\hline 12 & reagent & 0.01 & 7 & 11.21 & - \\
\hline
\end{tabular}


When oyster shells were difficult to react with phosphorric acid, the $\mathrm{Ca} / \mathrm{P}$ ratio became large from the unreacted calcium carbonate. Because the calcium ratio was lower than theoretical ratio, the initial calcium ratio in oyster shells was low. In the conditions of $0.1 \mathrm{~mol} / \mathrm{l}$ of phosphoric acid, the oyster shells heated at $400^{\circ} \mathrm{C}$ indicated the higher ratio of $\mathrm{Ca} / \mathrm{P}$ than those without heating. In previous paper about corbiculla shells, these calcium ratios in precipitates prepared from corbicula shells indicated the similar $\mathrm{Ca} / \mathrm{P}$ ratios with the theoretical ratios [10]. Oyster shells had the different behavior on these $\mathrm{Ca} / \mathrm{P}$ ratios from corbicula shells. Seashells had the various kinds of the reactivity with phosphoric acid.

Figure 1 portrays XRD patterns of samples prepared in various conditions. Samples prepared with $0.01 \mathrm{~mol} / \mathrm{l}$ of phosphoric acid indicated the weak unknown peaks (Figure 1(c)). Because the large amount of calcium carbonate was included in samples prepared with $0.01 \mathrm{~mol} / \mathrm{l}$ of phosphoric acid from Table 2, these peaks were related with calcium carbonate. Other samples prepared with 0.05 and $0.1 \mathrm{~mol} / \mathrm{l}$ of phosphoric acid had XRD peaks of calcium hydrogen phosphate dihydrate (Figures 1(a), (b), (d)). From the yields and the $\mathrm{Ca} / \mathrm{P}$ ratios, these samples included a certain degree of calcium carbonate. However, the peaks of calcium carbonate were not observed in these XRD patterns.

\subsection{Powder Properties of Precipitates}

Figure 2 presents SEM images of samples prepared in various conditions. Samples had the mixture of plate-like and oblong particles in spite of the concentration of phosphoric acid, the heating condition of oyster shells, and $\mathrm{pH}$ in the preparation condition [12]. The ratio of the oblong

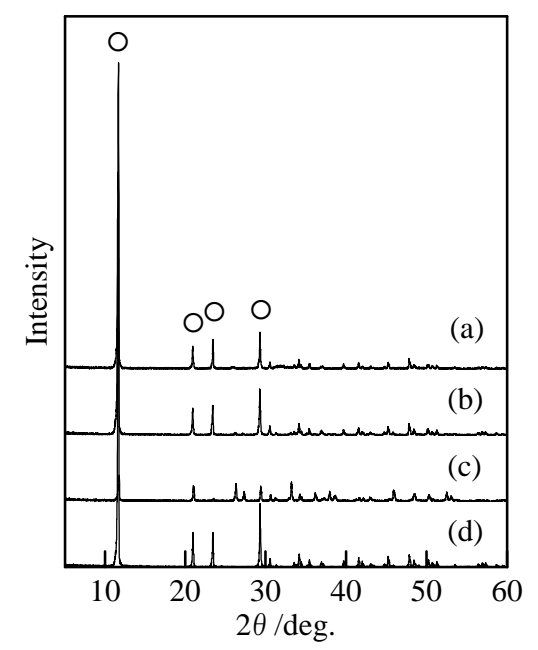

Figure 1. XRD patterns of samples obtained at $\mathbf{p H} 7$, (a) $\mathrm{H}_{3} \mathrm{PO}_{4} 0.1 \mathrm{~mol} / \mathrm{l}$, oyster shells without heating; (b) $0.05 \mathrm{~mol} / \mathrm{l}$, without heating; (c) $0.01 \mathrm{~mol} / \mathrm{l}$, without heating; (d) 0.1 $\mathrm{mol} / \mathrm{l}$, with heating; $\mathrm{O}: \mathrm{CaHPO}_{4} \cdot 2 \mathrm{H}_{2} \mathrm{O}$. particles increased in samples prepared with $0.01 \mathrm{~mol} / \mathrm{l}$ of phosphoric acid, because of the high $\mathrm{Ca} / \mathrm{P}$ ratio in precipitates.

Figure 3 shows the particle size distribution of samples prepared in various conditions. Samples prepared with 0.05 and $0.1 \mathrm{~mol} / \mathrm{l}$ of phosphoric acid and oyster shells without heating had the smaller particles than $100 \mu \mathrm{m}$ (Figures 3(a) and (b)). These samples indicated the similar yields and $\mathrm{Ca} / \mathrm{P}$ ratio (Tables 1 and 2). On the other hand, sample prepared with $0.01 \mathrm{~mol} / \mathrm{l}$ of phosphoric acid and oyster shells without heating had the large particles than $100 \mu \mathrm{m}$ (Figure 3(c)). Because this sample had high $\mathrm{Ca} / \mathrm{P}$ ratio (Table 2 ), these large particles contained a certain degree of calcium carbonate. Sample prepared with $0.1 \mathrm{~mol} / \mathrm{l}$ of phosphoric acid and oyster shells with heating had the medium particle size distribution (Figure 3(d)). The particle size distribution of samples was affected from their yields and the $\mathrm{Ca} / \mathrm{P}$ ratio in the precipitates.

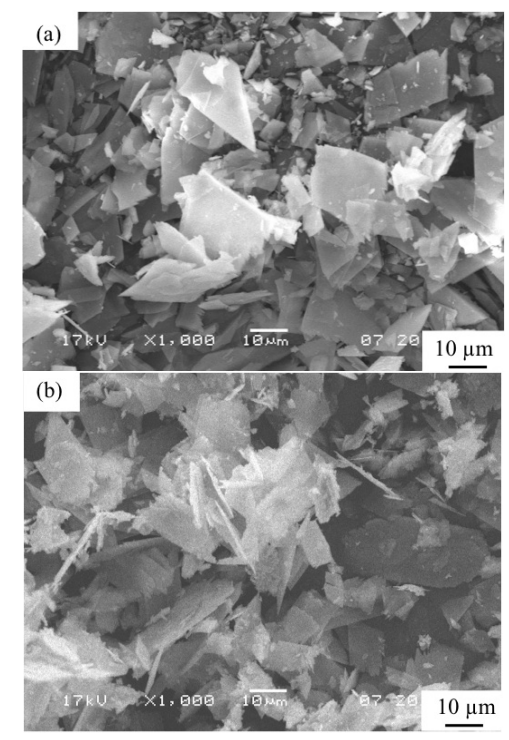

Figure 2. SEM images of samples, (a) $\mathrm{H}_{3} \mathrm{PO}_{4} 0.1 \mathrm{~mol} / \mathrm{l}$, oyster shells without heating; (b) $0.1 \mathrm{~mol} / \mathrm{l}$, with heating.

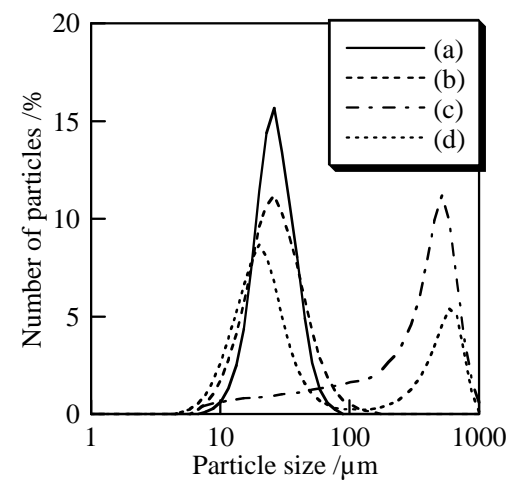

Figure 3. Particle size distributions of samples, (a) $\mathrm{H}_{3} \mathrm{PO}_{4}$ $0.1 \mathrm{~mol} / \mathrm{l}$, oyster shells without heating; (b) $0.05 \mathrm{~mol} / \mathrm{l}$, without heating; (c) $0.01 \mathrm{~mol} / \mathrm{l}$, without heating; (d) $0.1 \mathrm{~mol} / \mathrm{l}$, with heating. 


\section{Conclusion}

Calcium phosphates were prepared using oyster shells and phosphoric acid. The reactivity between oyster shells and phosphoric acid was estimated from the yield of calcium phosphate and carbonate and the $\mathrm{Ca} / \mathrm{P}$ ratio in precipitates. The yields in the conditions with 0.05 and 0.01 $\mathrm{mol} / \mathrm{l}$ of phosphoric acid were higher than those with 0.1 $\mathrm{mol} / \mathrm{l}$ of phosphoric acid, because of the unreacted calcium carbonate and insoluble part of oyster shells. The obtained samples prepared with 0.1 and $0.05 \mathrm{~mol} / \mathrm{l}$ of phosphoric acid indicated XRD peak pattern of calcium hydrogen phosphate dihydrate. Samples prepared with $0.01 \mathrm{~mol} / \mathrm{l}$ of phosphoric acid included a large amount of calcium carbonate.

\section{REFERENCES}

[1] J.-H. Jung, K.-S. Yoo, H.-G. Kim, H.-K. Lee and B.-H. Shon, "Reuse of Waste Oyster Shells as a $\mathrm{SO}_{2} / \mathrm{NO}_{\mathrm{x}} \mathrm{Re}-$ moval Absorbent," Journal of Industrial and Engineering Chemistry, Vol. 13, No. 4, 2007, pp. 512-517.

[2] D. S. Jeon and S. H. Yeom, "Recycling Wasted Biomaterial, Crab Shells, as an Adsorbent for the Removal of High Concentration of Phosphate," Bioresource Technology, Vol. 100, No. 9, 2009, pp. 2646-2649. doi:10.1016/j.biortech.2008.11.035

[3] J. Sawai, M. Satoh, M. Horikawa, H. Shiga and H. Kojima, "Heated Scallop-Shell Powder Slurry Treatment of Shredded Cabbage,” Journal of Food Protection, Vol. 64, No. 10, 2001, pp. 1579-1583.

[4] J. Sawai, H. Shiga and H. Kojima, "Kinetic Analysis of the Bactericidal Action of Heated Scallop-Shell Powder," International Journal of Food Microbiology, Vol. 71, No. 2-3, 2001, pp. 211-218. doi:10.1016/S0168-1605(01)00619-5
[5] M. P. Ginebra, T. Traykova and J. A. Planell, "Calcium Phosphate Cements as Bone Drug Delivery System: A Review," Journal of Controlled Release, Vol. 113, No. 2, 2006, pp. 102-110. doi:10.1016/j.jconrel.2006.04.007

[6] J. Ryu, K.-Y. Kim, B.-D. Hahn, J.-J. Choi, W.-H. Yoon, B.-K. Lee, D.-S. Park and C. Park, "Photocatalytic Nanocomposite Thin Films of $\mathrm{TiO}_{2}$-Beta-Calcium Phosphate by Aerosol-Deposition," Catalysis Communications, Vol. 10, No. 5, 2009, pp. 596-599. doi:10.1016/j.catcom.2008.10.045

[7] H. Onoda, H. Kawade and A. Takenaka, "Preparation of Calcium Phosphates from Resemble Phosphorus Waste Water and Sea Urchin Shells,” Journal of Ecotechnology Research, Vol. 15, No. 3-4, 2010, pp. 107-111.

[8] H. Onoda, M. Ichimura and A. Takenaka, "Preparation and Lead Removal Effects of Calcium Phosphates from Sea Urchin Shell," Phosphorus Research Bulletin, Vol. 24, 2010, pp. 49-53. doi:10.3363/prb.24.49

[9] Y. Yu, R. Wu and M. Clark, "Phosphate Removal by Hydrothermally Modified Fumed Silica and Pulverized Oyster Shells,” Journal of Colloid and Interface Science, Vol. 350, No. 2, 2010, pp. 538-543. doi:10.1016/j.jcis.2010.06.033

[10] H. Onoda, H. Nakanishi and A. Takenaka, "Preparation of Calcium Phosphates with Corbicula Shells," Journal of Ecotechnology Research, Vol. 16, No. 3-4, 2012, pp. 85-89.

[11] A. P. Davis, M. Shokouhian, H. Sharma and C. Minami, "Water Quality Improvement through Bloretention Media: Nitrogen and Phosphorus Removal," Water Environment Research, Vol. 78, No. 3, 2006, pp. 284-293. doi:10.2175/106143005X94376

[12] G. Madhurambai, R. Subha and S. C. Mojumdar, "Crystallization and Thermal Characterization of Calcium Hydrogen Phosphate Dihydrate Crystals," Journal of Thermal Analysis Calorimetry, Vol. 96, No. 1, 2009, pp. 7376. doi:10.1007/s10973-008-9841-1 